\title{
PENGARUH PELATIHAN, KOMPETENSI, DAN MOTIVASI KERJA TERHADAP KINERJA KARYAWAN GROUP CTO OFFICE PT INDOSAT
}

\author{
Rahma Sari Dewi ${ }^{\mathbf{1}}$, Eny Ariyanto ${ }^{2} \bowtie$ \\ Magister Manajemen Universitas Mercu Buana Jakarta \\ 1e-mail: rahmasari_dewi@yahoo.com \\ e-mail: eny_ariyanto@yahoo.com
}

\begin{abstract}
This study aims to determine and analyze the effect of training, competence and work motivation on employee performance at CTO Office Group PT Indosat Tbk Jakarta. The research population is all employees of CTO Office Group PT Indosat Tbk Jakarta, which is 100 people. Sampling methode using the census technique, that is because the population size is relatively small then all members of the population is taken into the sample research. Primary data were collected using questionnaires and secondary data were obtained from various sources such as journals, archived documents and literature. Hypothesis testing of research using multiple linear regression statistic technique. The results of hypothesis testing proved that the variables of training, competence and motivation of each work partially have a significant positive effect on employee performance. Coefficient $R^{2}=0.727$, which shows the findings that the variables training, competence and work motivation simultaneously able to explain significant variations of changes in employee performance variables of $72.7 \%$.
\end{abstract}

Keywords: training, competence, job motivatio, employee performance

\begin{abstract}
Abstrak
Penelitian ini bertujuan untuk mengetahui dan menganalisis pengaruh pelatihan, kompetensi dan motivasi kerja terhadap kinerja karyawan pada Group CTO Office, PT Indosat Tbk Jakarta. Populasi penelitian adalah seluruh karyawan Group CTO Office, PT Indosat Tbk Jakarta berukuran 100 orang. Metode pengambilan sampel (sampling) menggunakan teknik sensus, yaitu karena ukuran populasi relatif kecil maka semua anggota populasi diambil menjadi sampel penelitian. Data primer dikoleksi dengan menggunakan kuisioner dan data sekunder diperoleh dari berbagai sumber seperti jurnal, dokumen terarsip dan literatur. Pengujian hipotesis penelitian menggunakan teknik statistik regresi linier berganda. Hasil pengujian hipotesis membuktikan bahwa variabel pelatihan, kompetensi dan motivasi kerja masing-masing secara parsial mempunyai pengaruh positif signifikan terhadap kinerja karyawan. Koefisien $\mathrm{R}^{2}=0.727$, yaitu menunjukkan temuan bahwa variabel pelatihan, kompetensi dan motivasi kerja secara simultan mampu menjelaskan signifikan variasi perubahan variabel kinerja karyawan sebesar $72,7 \%$.
\end{abstract}

Kata kunci: pelatihan, kompetensi, motivasi kerja, kinerja karyawan 


\section{PENDAHULUAN}

Kinerja karyawan merupakan hal penting dari suatu organisasi, karena setiap organisasi tidak dapat maju dengan usaha dari satu atau dua individu saja, hal ini merupakan upaya kolektif dari semua anggota organisasi. Kinerja merupakan prestasi aktual karyawan dibandingkan dengan prestasi yang diharapkan dari karyawan selama periode tertentu yang dibandingkan dengan berbagai faktor seperti target standarisasi atau kriteria yang telah ditentukan manajemen dan disepakati bersama antara karyawan dan manajemen. Key Performance Index (KPI) digunakan untuk mengukur kinerja berdasarkan indikator yang tepat. Indikator sangat bergantung pada masing-masing jenis usaha dan rencana strategis dari organisasi. Banyak faktor yang mempengaruhi kinerja, di antaranya adalah pelatihan, kompetensi, dan motivasi kerja yang dimiliki oleh karyawan. Tujuan dari penelitian ini adalah untuk melihat pengaruh dari pelatihan, kompetensi, dan motivasi kerja terhadap kinerja karyawan pada Group CTO Office, PT Indosat.

Pada Group CTO Office, pencapaian kinerja dapat dilihat dari pencapaian KPI yang telah ditetapkan berdasarkan pada sharing Score Card seperti pada Tabel 1 sebagai berikut:

Berdasarkan Tabel 1 terlihat bahwa trend pencapaian kinerja meningkat. Hal ini tergambar pada pencapaian tahun 2015, yaitu meningkatnya persentase exceeds expectation (melampaui target) menjadi 44\%. Consistently exceed expectation juga meningkat dari tahun sebelumnya yaitu menjadi $16 \%$, serta menurunnya persentase meets expectation (mencapai target) menjadi 30\% dan partially meets expectation (mencapai target sebagian) menjadi $10 \%$. Tercatat pula pada tahun 2015 tidak ada karyawan yang mempunyai pencapaian kinerja need development (perlu pengembangan) atau sebesar $0 \%$.

Data yang disajikan adalah data pencapaian kinerja karyawan dengan indikator telah ditetapkan pada awal tahun dan bersifat sharing score card dan cascading. Sharing score card yang dimaksud adalah penetapan target bersama dari berbagai business unit di lingkungan Direktorat Teknologi dengan nilai distribusi proporsi target capaian yang telah ditetapkan di awal. Cascading adalah pendistribusian target per business unit kepada seluruh karyawan. Dari penjelasan tersebut dapat dipahami bahwa hasil penilaian pencapaian kinerja tidak mencerminkan pencapaian kinerja karyawan secara individu melainkan menggambarkan pencapaian kinerja dari business unit itu sendiri. Berdasarkan kondisi tersebut ma-ka diperlukan informasi tambahan yang dapat menggambarkan pencapaian kinerja karyawan yang diharapkan oleh management Group CTO Office.

Tabel 1.

Penilaian Kinerja Karyawan Berdasarkan KPI Sharing Score Card Periode Tahun 2013-2015

\begin{tabular}{lcccccc}
\hline \multirow{2}{*}{ Kategori } & \multicolumn{2}{c}{$\mathbf{2 0 1 3}$} & \multicolumn{2}{c}{$\mathbf{2 0 1 4}$} & \multicolumn{2}{c}{$\mathbf{2 0 1 5}$} \\
\cline { 2 - 7 } & Jumlah & $\mathbf{\%}$ & Jumlah & \% & Jumlah & \% \\
\hline Consistently Exceeds Expectations & 5 & 4 & 6 & 5 & 16 & 16 \\
Exceeds Expectations & 15 & 13 & 16 & 14 & 44 & 44 \\
Meets Expectations & 71 & 59 & 81 & 69 & 30 & 30 \\
Partially Meets Expectations & 14 & 12 & 10 & 8 & 10 & 10 \\
Development Needed & 15 & 13 & 5 & 4 & 0 & 0 \\
& $\mathbf{1 2 0}$ & $\mathbf{1 0 0}$ & $\mathbf{1 1 8}$ & $\mathbf{1 0 0}$ & $\mathbf{1 0 0}$ & $\mathbf{1 0 0}$ \\
\hline
\end{tabular}

Sumber: Data Sekunder Penilaian Karyawan Group CTO Office Periode 2013 - 2015 
Untuk melihat kesesuaian pencapaian kinerja karyawan dengan apa yang diharapkan oleh manajemen maka dilakukan koleksi data awal (preliminary survey). Responden pada preliminary survey adalah tingkat manajemen Group CTO Office yang terdiri dari Division Head dan Manager dengan responden berjumlah 20 orang. Kondisi yang diharapkan dapat tergambar dari survei ini adalah terlihatnya besaran pencapaian kinerja karyawan saat ini dari sudut pandang manajemen. Penilaian dibagi menjadi dua kriteria, yaitu rendah-tengah dan tinggi. Rendah-tengah adalah nilai kualitas pencapaian kinerja karyawan yang dianggap belum mampu memenuhi standar yang diharapkan manajemen. Sedangkan untuk kriteria tinggi adalah nilai kualitas pencapaian kinerja karyawan yang dianggap mampu untuk mencapai target kinerja yang diharapkan. Dari hasil preliminary survey tersaji data pada Tabel 2.

Tabel 2. Hasil Penilaian Kinerja pada 20 Orang Karyawan, Management Group CTO Office Tahun 2016

\begin{tabular}{|c|c|c|c|}
\hline \multirow[b]{2}{*}{ No. } & \multirow[b]{2}{*}{$\begin{array}{l}\text { Deskripsi } \\
\text { Indikator }\end{array}$} & \multicolumn{2}{|c|}{ Penilaian Kinerja } \\
\hline & & $\begin{array}{c}\text { Rendah- } \\
\text { Tengah } \\
(\%)\end{array}$ & $\begin{array}{c}\text { Tinggi } \\
\text { (\%) }\end{array}$ \\
\hline 1 & $\begin{array}{l}\text { Kemampuan } \\
\text { teknis }\end{array}$ & 68 & 32 \\
\hline 2 & Motivasi kerja & 75 & 25 \\
\hline 3 & $\begin{array}{l}\text { Kepuasan } \\
\text { kompensasi }\end{array}$ & 79 & 21 \\
\hline 4 & Kepemimpinan & 61 & 39 \\
\hline 5 & Kompetensi & 92 & 8 \\
\hline 6 & $\begin{array}{l}\text { Lingkungan } \\
\text { kerja }\end{array}$ & 74 & 26 \\
\hline 7 & $\begin{array}{l}\text { Budaya } \\
\text { organisasi }\end{array}$ & 82 & 18 \\
\hline 8 & Pelatihan & 86 & 14 \\
\hline 9 & Disiplin & 76 & 24 \\
\hline
\end{tabular}

Sumber: Data Primer Hasil Pra Survai pada Karyawan Management Group CTO Office

Data tersaji pada Tabel 2 menunjukkan penilaian kinerja karyawan dilihat dari berbagai demensi variabel. Kemampuan teknis dimaksudkan untuk melihat kemampuan karyawan teknis karyawan dalam penyelesaian pekerjaan. Motivasi kerja dimaksudkan untuk melihat seberapa besar motivasi karyawan dalam bekerja. Kepuasan kompensasi dimaksudkan untuk melihat tingkat kepuasan karyawan terhadap kompensasi yang diberikan perusahaan. Kepemimpinan ditujukan untuk melihat hubungan kepemimpinan dengan karyawan. Kompetensi adalah menilai kompetensi yang harus dimiliki oleh karyawan. Lingkungan kerja adalah menilai lingkungan kerja yang dibutuhkan oleh karyawan. Budaya organisasi adalah untuk menilai implementasi budaya organisasi di tempat kerja. Pelatihan adalah untuk menilai implementasi pelatihan yang dilakukan saat ini. Disiplin adalah untuk mengukur tingkat pelaksanaan disiplin karyawan.

Hasil dari pra riset menunjukkan bahwa dimensi variabel pelatihan dan kompetensi memiliki nilai kinerja pencapaian tinggi adalah sebesar $14 \%$ dan $8 \%$. Selanjutnya, secara berurutan pencapaian kinerja tinggi pada budaya organisasi sebesar 18\%, kepuasan kompensasi 21\%, disiplin sebesar $24 \%$, motivasi kerja sebesar $25 \%$, lingkungan kerja sebesar $26 \%$ dan kemampuan teknis serta kepemimpinan masing-masing sebesar $32 \%$ dan $39 \%$.

Fenomena yang terlihat adalah penilaian kinerja karyawan berdasarkan KPI yang diberlakukan saat ini pada Group CTO Office tidak mencerminkan kinerja karyawan sesungguhnya. Hal ini terlihat dengan masih kecilnya persentase kategori tinggi kinerja karyawan terhadap target yang diinginkan oleh manajemen Group CTO Office.

Berdasarkan uraian fenomena permasalahan tersebut di atas, maka dapat dirumuskan masalah penelitian sebagai berikut: apakah pelatihan, kompetensi, dan motivasi kerja berpengaruh terhadap kinerja karyawan Group CTO Office di PT Indosat? 
Selanjutnya, tujuan dari penelitian ini adalah untuk membuktikan dan menganalisis pengaruh pelatihan, kompetensi, dan motivasi kerja terhadap kinerja karyawan Group CTO Office PT. Indosat.

\section{KAJIAN PUSTAKA}

\section{Pengaruh Pelatihan terhadap Kinerja}

Pelatihan adalah bentuk pengembangan kompetensi untuk memenuhi tuntutan dalam upaya pemenuhan maksimal kinerja individu dan perusahaan. Pelatihan, menurut Elnaga dan Imran, (2013:140), dianggap sangat penting dan dinyatakan sebagai alat yang sangat penting bagi organisasi guna mengubah kinerja seluruh karyawan untuk menuju pertumbuhan dan keberhasilan suatu organiasi. Pelatihan menguntungkan kedua belah pihak baik karyawan maupun organisasi.

Terdapat banyak cara dalam menghadapi kekurangan pencapaian kinerja karyawan, dan pelatihan menjadi salah satu cara untuk mengatasi kekurangan tersebut. Dalam hal ini, Dabale et al., (2014:67) menyatakan bahwa kebutuhan pelatihan muncul dari kurangnya pencapaian kinerja, yang selanjutnya kekurangan tersebut dapat ditutup dengan pelatihan yang tepat. Menurut Athar dan Shah (2015:60), pelatihan sangat penting bagi kinerja karyawan terutama dalam hal peningkatan kompetensi serta dapat membantu perusahaan dalam mepertahankan karyawannya melalui kepuasan dan motivasi. Pesatnya perkembangan modernisasi glo-bal memberikan banyak tantangan bagi organisasi. Pelatihan dapat mengatasi hal tersebut dan dapat membuat kontribusi karyawan ke perusahaan menjadi lebih efisien.

Menurut Aguinis \& Kraiger, (2009:452) pelatihan didefinisikan sebagai pendekatan sistematis yang berdampak pada peningkatan pengetahuan, keterampilan, dan sikap dalam rangka meningkatkan efektivitas individu, tim, dan organisasi. Dimensi pelatihan yang diutarakan Aguinis dan Kraiger adalah: (a) peningkatan pengetahuan, (b) peningkatan keterampilan, (c) peningkatan sikap.

Sultana et al., (2012:647) dari hasil penelitiannya di perusahaan telekomunikasi di Pakistan menunjukkan bahwa terdapat pengaruh yang positip dan signifikan pada pelaksanaan pelatihan terhadap kinerja.

Berdasarkan beberapa hasil temuan penelitian di atas dapat disimpulkan bahwa pelatihan adalah suatu proses untuk meningkatkan kualitas sumber daya manusia atau karyawan yang dimiliki. Peningkatan yang diharapkan adalah peningkatan pengetahuan, peningkatan keterampilan, dan peningkatan perilaku dimana hasil dari peningkatan kualitas tersebut ditujukan untuk kinerja karyawan dan pencapaian tujuan organisasi. Rumusan hipotesis yang dapat dikemukakan adalah:

$\mathrm{H}_{1}$ : Pelatihan berpengaruh terhadap kinerja

\section{Pengaruh Kompetensi terhadap Kinerja}

Francoise dan Winterton (2006:54), menjelaskan bahwa yang dimaksud dengan kompetensi adalah sama dengan kemampuan, yaitu merupakan konsep menyatukan pengetahuan dan keterampilan dari berbagai elemen penting.

Menurut Athey dan Orth (1999:216) bahwakompetensi dapat didefinisikan sebagai suatu set dimensi pengamatan termasuk pengetahuan individu, keterampilan, sikap dan perilaku, kerjasama tim, proses dan kemampuan organisasi yang dikaitkan dengan kinerja tinggi dan memberikan organisasi keunggulan yang kompetitif dan berkelanjutan.

Dimensi dan indikator kompetensi menurut Francoise dan Winterson (2006:49) dibagi menjadi 4 dimensi yaitu dimensi kognitif, fungsional, sosial, dan meta. Hubungan antara 4 dimensi kompetensi yang terangkum dalam kerangka dimensi 
komprehensif. Dimana 3 dimensi pertama yaitu kognitif, fungsional, dan dan sosial memiliki nilai yang bersifat universal, dijelaskan bahwa yang digolongkan ke dalam dimensi kognitif adalah tingkatan pengetahuan, sedangkan tingkatan keterampilan ada pada dimensi fungsional dan dimensi sosial meliputi perilaku dan kebiasaan yang dimiliki karyawan. Dimensi meta berhubungan pada kemampuan individu dalam kemampuannya untuk menambah pengetahuan yang ada pada dirinya. Termasuk kemampuannya dalam membantu karyawan lainnya dalam meningkatkan kemampuan dan pengetahuannya.

Qomariah dan Fadli, (2011:72) dalam penelitiannya membagi kompetensi ke dalam dua dimensi yaitu kompetensi karyawan teknis dan kompetensi karyawan administrasi serta melihat pengaruh dari masing-masing dimensi tersebut. Dengan menggunakan analisis uji serempak bahwa kompetensi karyawan yang terdiri dari kompetensi teknis, kompetensi non teknis berpengaruh secara bersama-sama dan sangat nyata (highly significant) terhadap kinerja karyawan.

Jomhour(2010:66) dalam penelitiannya mengenai pengaruh kompetensi terhadap kinerja mengungkapkan bahwa terdapat pengaruh yang siginifikan antara kompetensi terhadap kinerja. Lebih lanjut untuk memastikan kembali hasil penelitiannya, Jomhour memecah kompetensi menjadi tiga dimensi dan meneliti kembali ketiga dimensi tersebut yaitu visi bersama, kerja sama, dan pemberdayaan dan melihat pengaruhnya pada kinerja. Hasil penelitian menunjukkan bahwa ketiga dimensi tersebut masingmasing memperlihatkan pengaruh yang signifikan terhadap kinerja.

Uraian tersebut di atas menunjukkan bahwa dalam kompetensi memiliki cakupan yang sangat kompleks, pada awalnya, adalah kemampuan atau karakteristik dasar yang dimiliki seseorang, tetapi dikembangkan menjadi lebih baik sesuai dengan kebutuhan. Pengembangan kompetensi ditujukan untuk membantu karyawan dalam meningkatkan kinerja. Rumusan hipotesis yang dapat dikemukakan adalah:
$\mathrm{H}_{2}$ : Kompetensi berpengaruh terhadap ki- nerja

\section{Pengaruh Motivasi Kerja terhadap Kin- erja}

MotivasimenurutHasibuan(2008:141), adalah pemberian daya penggerak yang menciptakan kegairahan kerja seseorang agar mereka mau bekerja sama, bekerja efektif, dan terintegrasi dengan segala daya upayanya untuk mencapai kepuasan.

Motivasi kerja menurut George dan Jones (2012:157), didefinisikan sebagai suatu dorongan secara psikologis kepada seseorang yang menentukan arah dari perilaku (direction of behavior) seseorang dalam organisasi, tingkat usaha (level of effort), dan tingkat kegigihan atau ketahanan di dalam menghadapi suatu halangan atau masalah (level of persistence). Jadi motivasi kerja dapat diartikan sebagai semangat kerja yang ada pada karyawan yang membuat karyawan tersebut dapat bekerja untuk mencapai tujuan tertentu.

McClelland dalam Anyim et al., (2012:33) menyatakan bahwa Achievement Motivation Theory berfokus pada tiga kebutuhan manusia yaitu: 1) Kebutuhan akan prestasi (need of achievement), yaitu keinginan untuk belajar dan unggul dalam kehidupannya, 2) Kebutuhan akan kekuasaan (need of power), yaitu kebutuhan untuk memimpin dan mempengaruhi orang lain, 3) Kebutuhan akan afiliasi (need of affiliation), yaitu kebutuhan untuk berinteraksi dengan orang lain. Teori motivasi McClelland ini menunjukkan bahwa motivasi yang bersifat intrinsik jauh lebih kuat dalam mempengaruhi kinerja dibanding dengam motivasi ekstrinsik. 
Penelitian yang dilakukan Larasati dan Gilang (2014:212) membagi penelitian menjadi tiga bagian variabel yaitu kebutuhan prestasi, kebutuhan afiliasi dan kebutuhan kekuasaan. Hasil pengujian dari masingmasing variabel baik bersifat parsial maupun simultan menunjukkan pengaruh yang signifikan terhadap kinerja karyawan. Berdasarkan penelitian yang dilakukan oleh Kiruja dan Mukuru (2013:81) ditemukan bahwa terdapat hubungan positif antara motivasi dan kinerja karyawan. Rumusan hipotesis yang dapat dikemukakan adalah:

$\mathrm{H}_{3}$ : Motivasi kerja berpengaruh terhadap kinerja.

Kerangka pemikiran yang dapat memberikan penjelasan terkait pengaruh antara variabel kompetensi, variabel pelatihan, dan variabel motivasi terhadap kinerja dapat tergambar seperti pada Gambar 1. sebagai berikut:

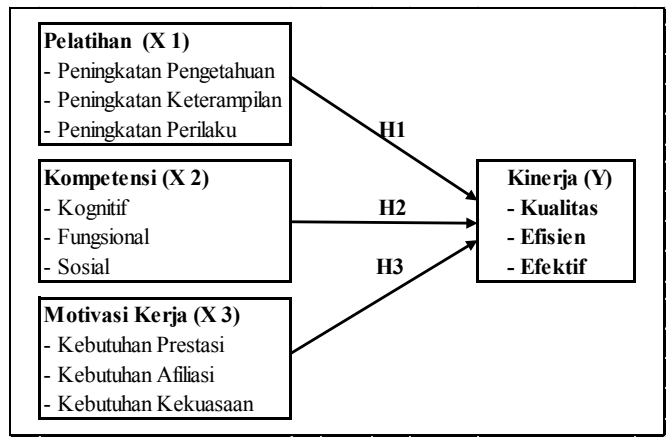

Gambar 1. Kerangka Pemikiran

\section{METODE PENELITIAN}

\section{Jenis Penelitian}

Penelitian ini menggunakan metode deskriptif kuantitatif yang bersifat kausalitas ekplanatif (penjelasan), yaitu menyoroti pengaruh antara variabel-variabel penelitian dan pengujian hipotesis yang telah dirumuskan sebelumnya. Eksplanatif memiliki tujuan untuk mengungkap hubungan antara variabelvariabel penelitian dan menguji hipotesis yang telah dirumuskan sebelumnya. Pengungkapan dengan menjelaskan hubungan 3 variabel $\mathrm{X}$ terhadap variabel $\mathrm{Y}$.

\section{Populasi dan Sampel}

Pengambilan sampel yang digunakan adalah sistem sensus atau saturation sampling, yaitu mengambil semua anggota populasi sebagai sampel penelitian. Populasi adalah seluruh pegawai Group CTO Office pada PT Indosat Tbk. yang berjumlah 100 orang karyawan dan terbagi ke dalam 5 divisi.

Metode pengambilan data yang digunakan dalam penelitian ini adalah metode survei, yaitu semua anggota sampel diobservasi melalui instrumen angket (kuesioner). Adapun teknik penelitian yang digunakan untuk menguji rumusan hipotesis adalah teknik statistik regresi linier berganda.

Data primer hasil pengukuran persepsi responden bersifat kualitatif. Dalam pengukurannya masing-masing variabel diukur menggunakan tiga dimensi dengan total item kuesioner sebanyak 36 butir pertanyaan. Variabel pelatihan diukur menggunakan dimensi peningkatan pengetahuan, peningkatan keterampilan, dan peningkatan perilaku (Aguinis dan Kraiger, 2009). Variabel kompetensi diukur menggunakan dimensi kognitif, fungsional, dan sosial (Francoise and Winterson 2006). Variabel motivasi kerja diukur menggunakan dimensi kebutuhan akan prestasi, kebutuhan akan kekuasaan, dan kebutuhan akan afiliasi. Variabel kinerja karyawan diukur menggunakan dimensi kualitas, efisien dan efektif (Moeheriono, 2012).

Data persepsi pengukuran pada masingmasing variabel penelitian bersifat kualitatif berskala Likert dan Numeric Differential seperti tersaji pada Tabel 3.

\section{HASIL DAN PEMBAHASAN}

\section{Karakteristik Responden}

Data hasil pengukuran melalui kuisioner terhadap 100 orang responden adalah sebagai berikut: diketahui bahwa jumlah responden laki-laki 66 orang (66\%) 
dan responden perempuan sebanyak 34 orang (34\%). Dari keseluruhan responden yang berusia kurang atau sama dengan 25 tahun sebanyak 13 orang (13\%), usia 26 sampai dengan 30 tahun sebanyak 29 orang (29\%), usia 31 sampai 40 tahun sebanyak 15 orang (15\%) dan usia 41 sampai 5543 orang (43\%). Masa kerja responden 1 sampai 3 tahun sebanyak 21 orang (21\%), masa kerja 4 sampai 10 tahun sebanyak 25 orang atau 25\%, masa kerja 11 sampai 20 tahun sebanyak 39 orang (39\%), dan masa kerja di atas 20 tahun sebanyak 15 orang atau (15\%). Adapun tingkat pendidikan responden dengan jenjang Diploma sebanyak 26 orang (26\%), jenjang Sarjana sebanyak 62 orang $(62 \%)$, dan jenjang pasca sarjana sebanyak 12 orang $(12 \%)$.

\section{Hasil Uji Validitas dan Reliabilitas Instru- men Penelitian}

Metode yang digunakan pada pengujian validitas instrumen menggunakan pendekatan korelasi Pearson product moment dengan ketentuan kevalidan instrumen apabila nilai $\mathrm{r}$ hitung $>$ nilai $\mathrm{r}$ tabel pada $\mathrm{n}=25$. Hasil uji validitas variabel pelatihan, variabel kompetensi, dan variabel motivasi kerja dihitung dari 25 sampel survei diketahui bahwa nilai $r$ hitung lebih besar dari nilai $r$ tabel, dimana nilai $r$ tabel adalah 0,39. Nilai instrument teruji bahwa $\mathrm{r}$ hitung $>$ nilai $\mathrm{r}$ tabel. Dari data tersebut dapat disimpulkan bahwa instrumen yang digunakan dapat dinyatakan valid dan keseluruhan instrumen pada masing-masing dapat dilanjutkan untuk membahas permasalahan dalam penelitian ini. Sedangkan hasil pengujian reliabilitas terhadap instrumen dilakukan dengan menggunakan rumus korelasi Alpha Cronbach. Semua instrumen pada masingmasing variabel secara konsisten memiliki nilai di atas nilai 0,6 (pelatihan 0,943; kompetensi 0,952 ; motivasi kerja 0,926 ; kinerja 0,941). Hasil pengujian tersebut dapat disimpulkan bahwa instrumen yang digunakan dapat dipercaya (reliabel) untuk menjawab permasalahan dalam penelitian ini.

Tabel 3. Ketentuan Penilaian Skala

\begin{tabular}{lcc}
\hline \multicolumn{1}{c}{ Kualitas Persepsi Responden } & \multicolumn{2}{c}{ Skor } \\
\cline { 2 - 3 } & Pernyataan Negatif & Pernyataan Positif \\
\hline $\begin{array}{l}\text { Sangat Tidak Setuju, Sangat Tidak Sesuai, Sangat Tidak Mampu, } \\
\text { Sangat Tidak Baik } \\
\text { Tidak Setuju, Tidak Sesuai, Tidak Mampu, Tidak Baik }\end{array}$ & 1 & 5 \\
Kurang Setuju, Kurang Sesuai, Kurang Mampu, Kurang Baik & 3 & 4 \\
Setuju, Sesuai, Mampu, Baik & 4 & 2 \\
Sangat Setuju, Sangat Sesuai, Sangat Sesuai, Sangat Baik & 5 & 1 \\
\hline
\end{tabular}




\section{Hasil Uji Asumsi Klasik Regresi}

Berdasarkan hasil pengujian normalitas pada variabel terikat yaitu kinerja karyawan didapat data tersebar linier dengan titik-titik penyebaran berada di sekitar garis diagonal serta penyebarannya titik-titik data mengikuti arah garis diagonal. Ini membuktikan bahwa model persamaan regresi yang terbentuk telah memenuhi asumsi normalitas. Hasil uji multikolinearitas menunjukkan bahwa semua variabel bebas dalam penelitian ini tidak menunjukkan adanya gejala multikolinieritas karena nilai VIF $<10$, sehingga variabel bebas telah memenuhi persyaratan regresi. Varians residual dari uji heteroskedastisitas menunjukkan bahwa terlihat titik-titik residual menyebar secara acak dan tidak membentuk pola tertentu yang jelas, seperti bergelombang, melebar kemudian menyempit. Selain itu titik-titik tersebut menyebar di atas dan di bawah angka pada sumbu Y. Artinya, dalam penelitian ini tidak terjadi gejala heterokedastisitas dan menghasilkan persamaan regresi yang baik.

\section{Analisis Regresi Berganda}

Penggunaan analisis regresi linier berganda dalam penelitian ini akan memperlihatkan apakah pelatihan, kompetensi, dan motivasi kerja mempengaruhi kinerja karyawan pada Group CTO Office dengan menggunakan observational data dari hasil penyebaran kuesioner. Hasil pengujian regresi linier berganda terangkum dalam Tabel 4.

Merujuk pada Tabel 4 didapat model persamaan regresi sebagai berikut:

Kinerja $=-4,445+0,363$ Pelatihan $+0,547$ Kompetensi + 0,174 Motivasi Kerja

\section{Analisis Koefisien Determinasi ( $R$-Square)}

Nilai Adjusted $R^{2}$ diketahui sebesar 0,727 atau $72.7 \%$, artinya variabel kinerja karyawan Group CTO Office yang dijelaskan oleh variabel pelatihan, kompetensi, dan motivasi kerja adalah sebesar $72,7 \%$ sedangkan sisanya sebesar $27,3 \%$ dijelaskan oleh variabel lain yang tidak diteliti dalam penelitian ini (nilai eror - E pada persamaan regresi linier berganda). Variabel tersebut diantaranya; kemampuan teknis menyelesaikan pekerjaan, kompensasi, kepemimpinan, kompetensi, dan kedisiplinan.

Temuan ini sejalan dengan penelitian terdahulu yang dilakukan oleh Subari dan Riady (2015:142) yang telah melakukan penelitian untuk melihat pengaruh pelatihan, kompetensi, dan motivasi kerja terhadap kinerja karyawan di PDAM Jawa Timur, menyatakan bahwa terdapat hubungan yang kuat dan positif antara pelatihan terhadap kinerja karyawan, baik bersifat parsial maupun bersama-sama.

Tabel 4. Hasil Uji Regresi Linier Berganda

\begin{tabular}{|c|c|c|c|c|c|c|}
\hline Model & Coefficients & $\begin{array}{c}\text { Standardized } \\
\text { Coefficients }\end{array}$ & \multirow[t]{2}{*}{$\mathbf{t}$} & \multirow[t]{2}{*}{ Sig. } & \multirow[t]{2}{*}{ F Hitung } & \multirow[t]{2}{*}{ Sig; } \\
\hline & Beta & Beta & & & & \\
\hline Konstanta & $-4,445$ & & & ,067 & & \\
\hline Pelatihan & ,363 & ,336 & 4,502 & 000 & & \\
\hline Kompetensi &, 547 & ,497 & 7,064 &, 000 & & \\
\hline Motivasi Kerja & , 174 & , 149 & 2,178 &, 032 & & \\
\hline $\mathrm{R}$ & ,858 & & & & & \\
\hline $\mathrm{R}^{2}$ & ,736 & & & & & \\
\hline Adjusted $\mathrm{R}^{2}$ &, 727 & & & & 89,003 &, 000 \\
\hline
\end{tabular}


Permasalahan yang dihadapi Group CTO Office saat ini adalah masih rendahnya pencapaian kinerja pada dimensi pelatihan, kompetensi, dan motivasi kerja karyawan. Hal yang diharapkan adalah peningkatan ketiga variabel tersebut secara bersama-sama mampu memberikan kontribusi maksimal terhadap kinerja karyawan Group CTO Office.

Usaha meningkatkan kualitas dari ketiga variabel tersebut harus datang dari manajemen, hal ini dimaksudkan agar pencapaian yang saat ini masih dirasakan kurang akan lebih membaik. Manajeman selayaknya menyampaikan secara langsung harapan tersebut terhadap karyawan baik dalam bentuk wishlist yang disampaikan secara verbal kepada karyawan atau dapat melalui media seperti individual score card. Media ini dimaksudkan agar keberhasilan dari karyawan dalam peningkatan kinerja dapat terukur dan dapat dipertanggungjawabkan. Tidak hanya itu, individual score card akan menjadi tantangan kepada karyawan untuk mendobrak batasan dirinya dan lebih lanjut akan memberikan kesempatan pada diri karyawan itu sendiri dalam meningkatkan kompetensi dirinya melalui berbagai media peningkatan kompetensi. Pelatihan akan menjadi opsi pertama dalam usaha untuk meningkatkan kompetensi diri, selanjutnya karyawan dapat menantang kemampuannya sendiri untuk lebih dapat berinovasi ataupun berkreasi terhadap batasan yang saat ini dirasakan dalam melaksanakan pekerjaan.

Hasil uji koefisien determinasi dapat disimpulkan bahwa secara empiris ketiga variabel yaitu pelatihan, kompetensi, dan motivasi kerja berpengaruh signifikan terhadap kinerja karyawan. Hubungan yang erat antara kinerja dengan pelatihan, mengarahkan pada keputusan peningkatan kesempatan pemberian pelatihan yang tepat kepada karyawan akan berpengaruh secara optimal kepada kinerja karyawan. Hubungan yang erat antara kinerja dengan kompetensi, mengarahkan kepada manajemen bahwa penting untuk mengkatkan kompetensi karyawan secara optimal sehingga hal ini berpengaruh terhadap kinerja karyawan secara optimal. Begitu pula dengan hubungan antara motivasi kerja dengan kinerja karyawan, hal ini memberikan arahan kepada manajemen bahwa semakin termotivasi karyawan akan berpengaruh terhadap hasil kinerja karyawan.

\section{Hasil Pengujian Hipotesis}

\section{Hipotesis 1}

Variabel pelatihan memiliki pengaruh positif signifikan ( $\mathrm{t}$ hitung 4,502 ; sig. 0,000 ) dengan korelasi yang cukup kuat $\left(\mathrm{SC} \beta_{1}\right.$ $0,336)$ terhadap kinerja, dengan demikian variabel pelatihan telah teruji dan pernyataan hipotesis 1 dapat diterima.

Penelitian yang telah dilakukan memberikan pembuktian secara empiris bahwa pelatihan memberikan pengaruh yang signifikan terhadap kinerja karyawan Group CTO Office. Pelatihan diharapkan mampu memberikan dampak positif terhadap peningkatan kinerja karyawan Group CTO Office.

Sejalan dengan definisi dari penelitian itu sendiri seperti yang diteorikan oleh Aguinis \& Kraiger (2009:452) pelatihan didefinisikan sebagai pendekatan sistematis yang berdampak pada peningkatan pengetahuan, keterampilan, dan sikap dalam rangka meningkatkan efektivitas individu, tim, dan organisasi. Dimensi pelatihan yang diutarakan Aguinis dan Kraiger adalah: 1) Peningkatan pengetahuan 2) Peningkatan keterampilan, 3) Peningkatan sikap.

Begitu pula dengan hasil penelitian terdahulu yang memiliki kesamaan dalam menilai pengaruh variabel pelatihan terhadap kinerja di antaranya adalah hasil penelitian yang dilakukan oleh Hafeez (2015:60) pada sebuah perusahaan farmasi di Karachi, Pakistan, dinyatakan bahwa pelatihan berpengaruh terhadap kinerja karyawan. 
Pelatihan yang baik akan membawa perusahaan ke arah yang lebih baik lagi. Onyango dan Wanyoik (2014:15) dalam penelitiannya terhadap karyawan kesehatan di Siaya County, Kenya menyatakan bahwa adanya hubungan yang kuat dan positif antara pelatihan dan kinerja karyawan. Penelitian yang dilakukan Kum et al., (2014:102) pada Escon Consulting menyatakan bahwa pelatihan berpengaruh terhadap kinerja karyawan. Juga dalam penelitian ini disimpulkan bahwa pelatihan dianggap sebagai kesempatan untuk meningkatkan produktivitas untuk jangka panjang. Melihat dari sisi modal manusia investasi kepada karyawan dalam bentuk pemberian pelatihan akan membuat perusahaan lebih mampu untuk bertahan dalam persaingan. Hasil penelitian yang dilakukan oleh Sultana et al., (2012:654), dinyatakan bahwa pelatihan memiliki pengaruh positif terhadap kinerja karyawan perusahaan telekomunikasi di Pakistan.

Permasalahan yang dihadapi Group CTO Office saat ini adalah masih rendahnya pencapaian kinerja karyawan pada dimensi pelatihan. PT Indosat sendiri sebagai salah satu perusahaan telekomunikasi terbesar di Indonesia telah memberikan perhatian besar pada pengembangan kualitas karyawan yang dimilikinya melalui pelatihan. Seperti informasi yang diperoleh di lapangan bahwa PT Indosat telah memberikan pelatihan terhadap karyawannya dalam jumlah yang cukup. Hal ini mengindikasikan bahwa terdapat kepedulian dari PT Indosat terhadap peningkatan kualitas karyawannya. Strategi penerapan pelaksanaan pelatihan selama ini adalah dengan memasukkan pelaksanaan pelatihan pada individual development program karyawan yang dibuat secara tahunan.

Pemberian pelatihan selayaknya diberikan dengan menggunakan beberapa strategi dalam pelaksanaannya. Hal ini dapat dilakukan melihat besarnya pengaruh pelatihan terhadap kinerja maka pelaksanaan pelatihan dengan strategi yang baik akan mampu memberikan dampak yang baik terhadap kinerja dan peningkatan kualitas karyawan.

Mengingat PT Indosat selalu mengadopsi perubahan teknologi yang selalu bergerak maka pelatihan itu sendiri sebaiknya dilihat sebagai kebutuhan karyawan untuk mengikuti perkembangan teknologi tersebut sehingga gap yang ada selama ini dapat mengikis dan pada akhirnya akan mampu mengimbangi setiap perkembangan.

Untuk melihat seberapa besar antara gap yang ada antara kebutuhan pelatihan dan harapan manajemen dapat dilakukan dengan melakukan pemetaan kondisi kualitas karyawan saat ini dengan arah atau tujuan dari organisasi itu sendiri. Hal ini dimaksudkan agar pemberian pelatihan dapat didesain dan disesuaikan dengan gap dan handicap karyawan dan secara tidak langsung menghindari ketidakefektifan dan ketidakefisienan dalam pemberian pelatihan. Harapannya adalah pemberian pelatihan menjadi lebih terarah, lebih terfokus dan lebih tepat guna bagi karyawan itu sendiri. Tujuan dari semua ini adalah adanya kontribusi maksimal yang diberikan karyawan dalam bentuk kinerja.

Secara empiris, hasil dari penelitian menggambarkan bahwa pelatihan berpengaruh secara positif dan signifikan terhadap kinerja perusahaan. Hal ini memberikan implikasi bahwa organisasi dalam hal ini adalah Group CTO Office harus lebih terfokus pada beberapa indikator yang berpotensi meningkatkan kinerja yaitu meliputi peningkatan pengetahuan, peningkatan keterampilan, dan peningkatan perilaku secara komprehensif.

Hipotesis 2

Variabel kompetensi memiliki pengaruh positif signifikan ( $\mathrm{t}$ hitung 7,064; sig. 0,000) dengan korelasi yang cukup 
kuat $(\mathrm{SC} \beta 2,497)$ terhadap kinerja, dengan demikian variabel kompetensi telah teruji dan pernyataan hipotesis 2 dapat diterima.

Hasil penelitian yang sudah dilakukan menunjukkanbahwakompetensimemberikan pengaruh yang signifikan terhadap kinerja karyawan Group CTO Office.

Francoise dan Winterton (2006:54), menjelaskan bahwa yang dimaksud dengan kompetensi adalah sama dengan kemampuan, yaitu merupakan konsep menyatukan pengetahuan dan keterampilan dari berbagai elemen penting. Pengetahuan merupakan kompetesi kognitif dan keahlian merupakan kompetensi fungsional serta kompetensi sosial yang dijelaskan oleh sikap dan perilaku.

Secara empiris penelitian ini menjelaskan bahwa kompetensi memberikan pengaruh yang signifikan terhadap kinerja karyawan Group CTO Office. Temuan ini sejalan dengan beberapa penelitian terdahulu yang menyatakan bahwa terdapat pengaruh positif antara kompetensi dengan kinerja karyawan. Di antaranya adalah penelitian yang Safwan et al. (2014:6) dalam penelitiannya menyatakan bahwa terdapat pengaruh yang signifikan antara kompetensi terhadap kinerja karyawan keuangan pada Pemerintah Daerah Pidie Jaya. Ismail dan Abidin (2010:35) juga dalam penelitiannya menyatakan bahwa secara keseluruhan, kompetensi merupakan faktor yang paling berpengaruh dan utama dalam menentukan kinerja karyawan, dimana komponen kognitif dirasakan lebih penting dikarenakan melibatkan tingkatan pengetahuan dari keterampilan karyawan sedangkan komponen fungsional dan sosial menempati urutan di bawahnya dalam penentuan pembentukan kompetensi karyawan. Osei dan Achkah (2015:7) juga menyimpulkan bahwa kompetensi sangat berpengaruh terhadap kinerja organisasi secara keseluruhan. Hal ini ditunjukkan dengan hasil penelitian yang menyatakan bahwa karyawan yang kompeten dan diberikan penugasan-penugasan khusus akan memberikan kontribusi terhadap kinerja organisasi.

Permasalahan yang dihadapi Group CTO Office saat ini adalah masih rendahnya pencapaian kinerja karyawan pada dimensi kompetensi. Hal ini dikarenakan bidang bisnis dari PT Indosat yang menuntut karyawan untuk selalu memperbaharui penguasaan teknologi, keahlian serta keterampilan mereka. Peningkatan kompetensi pada seluruh karyawan menjadi hal yang dirasa sangat perlu dilakukan sehingga karyawan dapat memberikan kontribusi kinerja terbaik pada perusahaan. Penguasaan teknologi terbaru menjadi hal yang sangat penting di PT Indosat, hal ini dikarenakan perusahaan Indosat yang berbasis teknologi selalu mengedepankan teknologi terbaru untuk memberikan layanan terbaik untuk pelanggannya. Kreatifitas serta inovasi sangat dibutuhkan dalam bisnis telekomunikasi, untuk itulah awareness terhadap pembaharuan keilmuan dan teknologi menjadi bagian yang sangat penting yang harus dimiliki oleh karyawan PT Indosat, terlebih lagi pada Group CTO Office.

Saat ini dari manajemen Group CTO Office belum melakukan pemetaan kompetensi karyawan. Hal ini berdampak pada ketidakjelasan tujuan pengembangan karyawan. Terkait dengan kondisi tersebut maka pihak manajemen harus melihat kemampuan aset karyawan yang dimilikinya. Perlu dilakukan suatu assessment yang dapat membantu manajemen untuk melihat gap yang ada antara kompetensi karyawan saat ini dengan kompetensi yang diharapkan. Kompetensi gap dibutuhkan untuk melihat kelemahan dan kelebihan karyawan. Selanjutnya hasil kompetensi gap dapat dijadikan dasar untuk melakukan pengembangankaryawan darisisigap masingmasing. Untuk itu peningkatan kompetensi karyawan harus secara strategis dilakukan. Peningkatan kompetensi hendaknya dibuat secara sistematis dari perencanaan, teknis 
pelaksanaan, sampai dengan implementasi.

Sebagai perusahaan telekomunikasi terbesar di Indonesia, PT Indosat harus mengutamakan pengembangan kompetensi dari sumber daya manusia yang dimilikinya, peningkatan kompetensi pada dimensi fungsional yaitu pada hal yang bersifat teknis keilmuan serta penguasaan teknologi harus benar diberi penekanan konsentrasi lebih, hal ini dikarenakan bidang usaha dari PT Indosat yang memang spesifik dan selalu harus beradaptasi dengan perkembangan teknologi. Peningkatan kompetensi dari sisi dimensi kognitif maupun sosial juga harus dikembangkan bersama dengan porsi yang sama, semua ditujukan pada penciptaan sumber daya manusia yang handal dan memiliki kemampuan tinggi untuk menyelesaikan masalah dan berinteraksi secara positif dengan lingkungan kerjanya. Lebih jauh diharapkan peningkatan kompetensi secara keseluruhan dapat membuat sumber daya yang ada pada Group CTO Office mampu bersaing mengikuti perkembangan teknologi dan persaingan usaha di masa depan.

Dalam hal implementasi teknis, pengembangan kompetensi karyawan adalah kemampuan setiap karyawan dalam menerjemahkan tugas dan fungsi masingmasing ke dalam strategi serta perencanaan kerja. Peningkatan terhadap kemampuan ini akan membawa karyawan untuk lebih terarah dalam pencapaian tujuan dan dalam menyelesaikan pekerjaan. Penetapan standar atau baseline pekerjaan yang lebih menantang akan membawa pada peningkatan kualitas yang lebih baik lagi.

Layanan pelanggan baik pelanggan internal maupun pelanggan eksternal menuntut karyawan untuk bisa lebih meningkatkan kemampuannya dalam lingkup sosial. Stakeholder selayaknya menjadi target dari layanan yang diberikan. Peningkatan kompetensi di bidang sosial menjadi salah satu hal yang perlu mendapatkan perhatian dalam pengembangannya.

Secara empiris penelitian ini menjelaskan bahwa kompetensi memberikan pengaruh signifikan dan korelasi tertinggi terhadap kinerja karyawan Group CTO Office. Hasil penelitian tersebut dapat diartikan bahwa semakin baik kompetensi yang dimiliki oleh karyawan maka akan berdampak positif pada kinerja karyawan. Strategi peningkatan kompetensi harus mengena pada semua dimensi baik itu dimensi kognitif, fungsional maupun dimensi sosial. Mengingat kompetensi dalam penelitian ini memiliki nilai korelasi tertinggi dari keseluruhan variabel yang diuji, maka peningkatan kompetensi menjadi salah satu kesempatan yang sangat baik dalam peningkatan kinerja karyawan Group CTO Office.

\section{Hipotesis 3}

Variabel motivasi kerja memiliki pengaruh positif signifikan ( $\mathrm{t}$ hitung 2,178; sig. 0,032) dengan korelasi yang sangat lemah $\left(\mathrm{SC}_{3}, 0,149\right)$ terhadap kinerja, dengan demikian variabel motivasi kerja telah teruji dan pernyataan hipotesis 3 dapat diterima.

Hasil penelitian yang sudah dilakukan menunjukkan bahwa motivasi kerja memberikan pengaruh yang signifikan terhadap kinerja karyawan Group CTO Office. Motivasi yang dimaksud pada penelitian disini adalah keinginan dari karyawan untuk berafiliasi yaitu berinteraksi satu sama lain sehingga pada ujungnya adalah kemampuan karyawan dalam bekerja sama dengan ritme yang tepat dan tercipta suatu teamwork yang solid. Menumbuhkan keinginan untuk berprestasi mendorong karyawan untuk terus mengedepankan kualitas hasil kerja serta keinginan terhadap kekuasaan menumbuhkan semangat berkarir pada bidang kerja yang digeluti.

MotivasimenurutHasibuan(2008:141), 
adalah pemberian daya penggerak yang menciptakan kegairahan kerja seseorang agar mereka mau bekerja sama, bekerja efektif, dan terintegrasi dengan segala daya upayanya untuk mencapai kepuasan.

Penelitian terdahulu yang telah dilakukan juga senada dengan hasil yang diperoleh oleh peneliti. Salleh et al,. (2011: 151) pada penelitiannya dalam melihat pengaruh motivasi terhadap performasi kerja pegawai negeri yang ada di Malaysia menyimpulkan bahwa motivasi kerja berpengaruh meningkatkan kinerja karyawan. Sedangkan penelitian yang dilakukan Shahzadi et al., (2014:164) menyimpulkan bahwa motivasi kerja berpengaruh secara positif terhadap kinerja karyawan.

Permasalahan yang dihadapi Group CTO Office saat ini adalah masih rendahnya pencapaian kinerja karyawan pada dimensi motivasi kerja. Keinginan karyawan untuk berprestasi masih belum terpacu, hal ini dapat disebabkan kurangnya stimulasi dari manajemen yang dapat memacu karyawan untuk dapat lebih aktiflagi dalam memacu diri mereka untuk lebih berprestasi. Begitu pula dengan motivasi karyawan dalam berafiliasi. Meskipun termasuk faktor terlemah dalam hubungannya dengan kinerja, tetapi tetap memiliki potensi dalam mempengaruhi peningkatan kinerja.

Manajemen Group CTO Office memahami bahwa motivasi kerja yang dimiliki karyawan akan berpengaruh pada hasil kerja yang diberikan. Kesempatan berkompetisi, kesempatan berkarir serta eksistensi dari karyawan menjadi faktor yang saat ini harus diperhatikan oleh manajemen untuk meningkatkan motivasi kerja karyawan. Kesempatan berkompetisi membuat karyawan menjadi lebih bersemangat dalam menghadapi persaingan. Persaingan yang diciptakan oleh perusahaan akan mampu meningkatkan prestasi karyawan untuk lebih maju lagi. Kesempatan berkarir memberikan motivasi pada karyawan untuk membuat perencanaan strategis untuk perkembangan potensi kompetensinya serta meningkatkan kemampuan karyawan untuk bisa melihat kesempatan yang ada atau bahkan menciptakan peluang dalam peningkatan karir mereka. Pengakuan atas eksistensi karyawan menjadi pemacu kerja tersendiri bagi karyawan. Penghargaan atas komitmen, integritas, serta kualitas output yang diberikan akan meningkatkan motivasi karyawan secara maksimal.

Hasil penelitian secara empiris dapat diartikan bahwa kinerja sangat dipengaruhi oleh seberapa besar motivasi yang dimiliki karyawannya. Hal ini memberikan implikasi bahwa penting bagi setiap karyawan Group CTO Office memiliki motivasi kerja yang kuat sehingga karyawan dapat memberikan kontribusi maksimal untuk pencapaian kinerja.

\section{SIMPULAN DAN SARAN}

\section{Simpulan}

Penelitian yang sudah dilakukan menunjukkan hasil yang signifikan dari ketiga variabel independen yaitu: pelatihan, kompetensi, dan motivasi kerja terhadap variabel dependen yaitu kinerja karyawan. Artinya faktor pelatihan, kompetensi, dan motivasi kerja merupakan hal yang sangat penting dalam memengaruhi kinerja karyawan.

1. Kompetensi berpengaruh positif dan signifikan terhadap kinerja serta memiliki korelasi tertinggi terhadap kinerja. Artinya kompetensi menjadi variabel yang memiliki peluang terbesar dalam mempengaruhi kinerja. Pada variabel kompetensi korelasi tertinggi terdapat pada dimensi kognitif, hal ini menggambarkan bahwa perbaikan terhadap dimensi kognitif akan sangat berdampak pada peningkatan kinerja. Group CTO 
Office dapat memanfaatkan kondisi ini untuk memperbaiki kompetensi karyawannya karena indikator lainnya juga memiliki korelasi yang cukup tinggi sehingga dapat disimpulkan bahwa peningkatan kompetensi dari semua aspek akan sangat memberikan pengaruh positif pada kinerja karyawan. Hal ini dapat memberikan gambaran kepada manajemen Group CTO Office untuk lebih memfokuskan pengembangan kompetensi karyawan secara keseluruhan karena peluang peningkatan kinerja melalui peningkatan kompetensi sangat tinggi. Peningkatan kinerja akan terlihat pada tingkat penguasaan teknologi dan keilmuan serta kemampuan dalam menyelesaikan permasalahan dan berinteraksi di dalam tim.

2. Pelatihan berpengaruh positif dan signifikan terhadap kinerja karyawan. Artinya kinerja karyawan dapat dipengaruhi secara signifikan terhadap pelatihan yang diberikan. Pada variabel pelatihan, peningkatan keterampilan memiliki korelasi tertinggi terhadap peningkatankinerja, hal ini memberikan kesempatan kepada manajemen Group CTO Office untuk dapat memanfaatkan kondisi yang ada untuk meningkatkan kinerja melalui peningkatan keterampilan. Indikator lainnya juga menunjukkan korelasi yang tinggi terhadap peningkatan kinerja. Artinya kondisi ini dapat dimanfaatkan semaksimal mungkin oleh pihak manajemen Group CTO Office sebagai peluang untuk meningkatkan kinerja karyawan. Pemberian pelatihan untuk meningkatkan hard skill, soft skill, maupun kemampuan ekspertis akan memberikan kontribusi maksimal terhadap kualitas karyawan. Pemberian pelatihan yang dikonsentrasikan untuk peningkatan perilaku juga akan berdampak dalam kemampuan karyawan untuk bekerja lebih baik dalam tim, meningkatnya kemampuan verbal dan interpersonal skill karyawan. Peningkatan kinerja akan dapat terlihat dari meningkatnya efektifitas, efisiensi, dan kualitas hasil kerja dari karyawan.

3. Motivasi kerja berpengaruh positif dan signifikan terhadap kinerja. Artinya, motivasi kerja memiliki potensi dalam meningkatkan kinerja karyawan, karyawan yang memiliki motivasi kerja yang tinggi akan memberikan kinerja yang baik. Korelasi tertinggi antara motivasi kerja dengan kinerja adalah tingkat kebutuhan akan prestasi. Hal ini memberikan gambaran kepada manajemen Group CTO Office bahwa perlunya memberikan stimulan pada karyawan untuk memacu kinerja karyawan. Semangat persaingan serta kerja sama tim harus ditumbuhkan. Tidak berhenti sampai disini, peran manajemen juga sangat dibutuhkan untuk meningkatkan kinerja yaitu dengan memberikan. Motivasi kerja dapat membawa karyawan menjadi lebih bersemangat dalam melaksanakan tugas-tugas yang diberikan. Pemberian target yang menantang akan memacu karyawan untuk lebih maksimal lagi dalam pencapaian kinerja. Peningkatan kinerja dapat dilihat dari kualitas hasil kerja yang dihasilkan.

4. Faktor pelatihan, kompetensi, dan motivasi kerja merupakan hal yang sangat penting dalam memengaruhi kinerja karyawan. Memberikan kesempatan untuk peningkatan elemen-elemen yang mewakili variabel-variabel bebas tersebut akan memberikan hasil optimal terhadap peningkatan kinerja karyawan.

\section{Saran}

Berdasarkan dari hasil penelitian dan 
kesimpulan, agar kinerja karyawan Group CTO Office dapat ditingkatkan maka perlu dilakukan hal-hal sebagai berikut:

1. Tingkat keeratan yang tinggi antara kompetensi dan kinerja memberikan peluang besar bagi manajemen Group CTO Office untuk dapat dimanfaatkan sebagai faktor peningkatkan kinerja karyawan. Saat ini manajemen sudah konsisten dalam kesesuaian penetapan latar belakang pendidikan, hal ini sebaiknya tetap dipertahankan sebagai baseline untuk mendapatkan karyawan yangkompeten.Lebihlanjutmanajemen perlu melakukan assessment terhadap kualitas kompetensi masing-masing karyawan agar dapat tergambar kondisi sebenarnya dan seberapa jauh rentang gap yang ada antara kondisi yang ada dengan harapan manajemen. Perlu dilakukan penyelarasan tujuan organisasi dengan kondisi kompetensi yang ada. Kompetensi gap dari hasil assessment akan menjadi dasar untuk pembuatan rencana peningkatan kompetensi untuk masing-masing karyawan. Tujuan dari rencana yang dibuat adalah untuk untuk mengikis rentang gap yang ada. Perencanaan meliputi penetapan tujuan serta teknis implementasi agar kompetensi dapat maksimal ditingkatkan. Pelaksanaan rencana pengembangan kompetensi dilakukan bertahap. Hal ini sebaiknya sudah didesain pada saat penetapan target dan pada saat pembuatan rencana teknis implementasi. Pelaksanaan dibagi menjadi beberapa tingkatan agar setiap perkembangan terpantau dan dapat dianalisis untuk kemungkinan penyesuaian pada tahap berikutnya. Manajemen membuat skala ukuran sebagai pedoman yang disepakati untuk mengukur peningkatan kompetensi karyawan. Indikator dari peningkatan kinerja juga harus dibuat dengan tujuan agar setiap perkembangan terukur. Hal ini akan mempermudah manajemen dalam membaca progress serta melakukan penyesuaian terhadap arah pengembangan kompetensi karyawan. Pada akhirnya perlu dilakukan evaluasi terhadap pelaksanaan. Untuk melihat kesesuaian antara tujuan pengembangan kompetensi dengan hasil dari implementasi. Hal ini perlu dilakukan tidak hanya untuk melihat kesesuaian pelaksanaan dengan tujuan tetapi untuk melihat apakah masih ada faktor lain yang harus dibenahi dalam usaha manajemen untuk meningkatkan kompetensi. Hasil evaluasi dapat membantu untuk melihat apakah penurunan besaran rentang gap kompetensi yang diharapkan manajemen sudah tercapai.

2. Untuk meningkatkan kinerja karyawan manajemen Group CTO Office dapat memanfaatkan hubungan yang terdapat antara variabel pelatihan dengan kinerja. Manajemen Group CTO Office selayaknya membuat pemetaan kondisi karyawan saat ini dengan tujuan untuk mendapatkan gap terhadap kondisi saat ini dengan kebutuhan pelatihan karyawan. Pemberian pelatihan secara konsisten seperti yang telah diberikan selama ini perlu untuk dipertahankan tetapi dalam implementasinya masih harus perlu dilakukan peninjauan ulang. Kebutuhan pelatihan harus dipetakan secara komprihensif sehingga tujuan dari pemberian pelatihan dapat meliputi seluruh kebutuhan peningkatan kualitas karyawan. Peningkatan kualitas baik hard skill maupun soft skill, peningkatan kemampuan eks-pertis serta peningkatan perilaku menjadi aspek yang harus diperhatikan oleh manajemen. Hasil dari pemetaan kompetensi dapat membantu dalam penyusunan pemetaan gap pelatihan, 
hal ini ditujukan untuk menilai kebutuhan pelatihan karyawan terhadap gap kompetensi yang dimiliki serta kebutuhan pelatihan terhadap pekerjaan yang dilakukan saat ini. Untuk itu maka pemberian pelatihan yang tepat baik dari pemilihan jenis pelatihan maupun dari pemilihan materi yang diberikan akan lebih bermanfaat dalam meningkatkan kualitas serta kinerja karyawan. Untuk melihat seberapa besar pelatihan yang diberikan berpengaruh terhadap kinerja, serta untuk melihat ketepatan dari pemberian pelatihan kepada karyawan, perlu dilakukan evaluasi berkala atas hasil dari pemberian pelatihan. Hal ini dimaksudkan agar pihak manajemen Group CTO Office dapat melihat hasil langsung dari pelatihan yang sudah diberikan, juga untuk mengukur apakah masih diperlukan pelatihan lanjutan kepada karyawan atau diperlukan pelatihan jenis lainnya yang dapat membantu karyawan dalam meningkatkan kinerja.

3. Untuk memahami seberapa besar motivasi kerja yang dimiliki oleh karyawan yang berada pada Group CTO Office maka sebaiknya dilakukan pencarian informasi melalui motivation survey index yang disebarkan ke karyawan. Tujuan dari sebaran survey ini adalah untuk memberi gambaran seberapa besar motivasi kerja yang dimiliki karyawan. Berangkat dari hasil survey tersebut maka dapat dibuat suatu strategi dan perencanaan yang ditujukan untuk meningkatkan motivasi kerja. Rencana peningkatan motivasi kerja sebaiknya dibuat secara sistematis, karyawan diberikan stimulasi seperti penekanan yang jelas untuk reward dan punishment, penetapan target-target yang menantang, serta pemberian kesempatan bagi karyawan untuk lebih dapat menuangkan kreativitas atau terobosan-terobosan baru dalam pekerjaan yang dikerjakan. Pembentukan kelompok diskusi kecil seperti Forum Group Discussion juga sangat efektif untuk menmberikan stimulasi bagi karyawan agar dapat lebih melatih karyawan dalam mengasah kemampuan mereka dalam hal leadership dan interpersonal skill. Transparansi terhadap jenjang karir dan kesempatan berkarir juga dirasa perlu dilakukan sehingga diharapkan karyawan memilikivisibilitas lebihjelas terhadap tujuan karirnya. Pada akhirnya semua stimulan ini diharapkan mampu meningkatkan motivasi kerja karyawan Group CTO Office. Manajemen Group CTO Office sebaiknya membuat metode pengukuran perkembangan motivasi kerja karyawan. Hal ini dimaksudkan untuk melihat seberapa besar progress yang telah dicapai setelah dilakukan pemberian stimulasi kepada karyawan. Evaluasi atas pencapaian peningkatan motivasi kerja harus dilakukan untuk melihat seberapa berpengaruh pelaksanaan dari usaha peningkatan motivasi terhadap kinerja karyawan. Seberapa penyesuaian yang dibutuhkan serta melihat kembali rentang gap antara harapan manajemen dengan kondisi yang diharapkan.

\section{REFERENSI}

Aguinis H. and Kraiger K. 2009. Benefits of Training and Development for Individuals and Teams, Organizations, and Society. Annual Review of Psychology. Vol. 60: 451-474.

Anyim C.F., Chidi O.C., Badejo A.E. 2012. Motivation and Employee's Performance in the Public and Private Sectors in Nigeria. International Journal of Business Administration. Vol. 3 (1): 31-40. 
Athar R. dan Shah, F.M. 2015. Impact of Training on Employee Performance, Banking Sector Karachi. IOSR Journal of Business and Management. Vol. 17 (11): 58-67.

Athey T.R. and Orth M.S. 1999. Emergency Competency Method for The Future. Human Resource Management, fall. Vol. 38 (3): 215-226.

Dabale, W.P., Nelson J., Mentline N. 2014. The Relationship between Training and Employee Performance: The Case of Mutare City Council, Zimbabwe, International Journal of Human Resource Studies. Vol. 4 (4): 61-72.

Elnagal, A. dan Imran, A. 2013. The Effect of Training on Employee Performance. European Journal of Business and Management. Vol. 5 (4): 137-147.

Françoise D., Winterton J, Stringfellow E. 2006. Typology of Knowledge, Skills and Competences: Clarification of The Concept and Prototype. European Centre for the Development of Vocational Training. Vol. 64 (3048): 1-121.

George, J. M. \& Jones, G. R. 2012. Understanding and Managing Organizational Behaviour. 6th edition. Reading MA: Prentice Hall.

Hafeez, Uzma. 2015. Impact of Training on Employees Performance (Evidence from Pharmaceutical Companies in Karachi, Pakistan). Business Management and Strategy. Vol. 6 (1): 49-64.

Hasibuan, Malayu. 2008. Manajemen Sumber Daya Manusia. Jakarta: Bumi Aksara.

Ismail R, Abidin S. 2010. Impact of Workers' Competence on Their Performance in The Malaysian Private Service
Sector, Business and Economic Horizons. Vol. 2 (2): 25-36.

Jomhour, Manar Salah. 2010. The Impact of Core Competence on Organizational Performance an Applied Study on Paint Industry in The United Arab Emirates. Master Thesis. Middle East University. Unite Arab Emirates.

Kiruja E.K., Mukuru E. 2013. Effect of Motivation on Employee Performance in Public Middle Level Technical Training Institutions in Kenya. International Journal of Advances in Management and Economics. Vol. 2 (4): 73-82

Kum F, Cowden R, Karodia A. 2014. The Impact of Training and Development on Employee Performance: a Case Study of Escon Consulting, Singaporean Journal of Business Economics and Management Studies. Vol. 3 (3): 72-105.

Larasati S., Gilang A. 2014. Pengaruh Pengaruh Motivasi Kerja terhadap Kinerja Karyawan Wilayah Telkom Jabar Barat Utara (Witel Bekasi). Jurnal Manajemen dan Organisasi. Vol. 5 (3): 201-2013.

Moeheriono. 2012. Pengukuran Kerja Berbasis Kompetensi. Jakarta: Raja Grafindo Persada.

Osei, A.J. dan Ackah, O. 2015. Employee's Competency and Organizational Performance in The Pharmaceutical Industry an Empirical Study of Pharmaceutical Firms in Ghana, International Journal of Economics, Vol. III (3): 1-9.

Qomariah I, Fadli. 2011. Pengaruh Perencanaan dan Kompetensi Karyawan terhadap Kinerja Karyawan pada PT Indonesia Asahan Alumunium Kuala Tanjung, Jurnal 
Ekonom. Vol. 14 (2): 63 - 73.

Safwan, N. dan Abdullah, S. 2014. Pengaruh Kompetensi dan Motivasi terhadap Kinerja Pengelolaan Keuangan Daerah pada Pemerintah Daerah Kabupaten Pidie Jaya, Jurnal Akuntansi, Vol. 3 (1): 133- 139.

Salleh F., Zaharah D., Wan A.W.A., Nur H.M.Y. 2011. The Effect of Motivation on Job Performance of State Government Employees in Malaysia. International Journal of Humanities and Social Science. Vol. 1 (4): 147-154.

Shahzadi I., Javed A., Pirzada, S.S., Nasreen S., Khanam F. 2014. Impact of Employee Motivation on Employee
Performance. European Journal of Business and Management. Vol. 6 (23): 159-166.

SubariS, Raidy H. 2015. Influence of Training, Competence and Motivation on Employee Performance, Moderated by Internal Communications. American Journal of Business and Management. Vol. 4 (3): 133-145.

Sultana A, Irum S, Ahmed K, Mehmood N. 2012. Impact of Training on Employee Performance: a Study of Telecommunication Sector in Pakistan, Interdisciplinary Journal of Contemporary Research in Business. Vol. 4 (6): 646-661. 